\title{
Stylolites and stylolite networks as primary controls on the geometry and distribution of carbonate diagenetic alterations
}

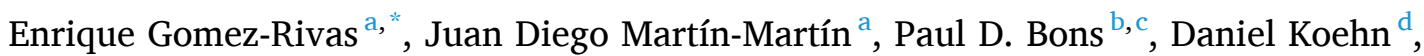 \\ Albert Griera $^{\mathrm{e}}$, Anna Travé ${ }^{\mathrm{a}}$, Maria-Gema Llorens ${ }^{\mathrm{f}}$, Elliot Humphrey ${ }^{\mathrm{g}}$, Joyce Neilson ${ }^{\mathrm{g}}$ \\ a Departament de Mineralogia, Petrologia i Geologia Aplicada, Facultat de Ciències de la Terra, Universitat de Barcelona, Martí i Franquès s/n, 08028, Barcelona, Spain \\ ${ }^{\mathrm{b}}$ Department of Geosciences, Eberhard Karls University of Tübingen, Wilhelmstr. 56, 72074, Tübingen, Germany \\ ${ }^{c}$ School of Earth Science and Resources, China University of Geosciences, Xueyuan Road 29, Haidian district, 100083, Beijing, China \\ d GeoZentrum Nordbayern, University Erlangen-Nuremberg, Schlossgarten 5, 91054, Erlangen, Germany \\ ${ }^{\mathrm{e}}$ Departament de Geologia, Universitat Autònoma de Barcelona, 08193, Bellaterra (Cerdanyola del Valles), Barcelona, Spain \\ ${ }^{\mathrm{f}}$ Geosciences Barcelona - CSIC, 08028, Barcelona, Spain \\ ${ }^{g}$ School of Geosciences, University of Aberdeen, King's College, AB24 3UE, Aberdeen, Scotland, UK
}

\section{A R T I C L E I N F O}

\section{Keywords:}

Stylolite

Dolomitization

Fluid flow

Barrier

Baffle

Conduit

Diagenesis

\begin{abstract}
A B S T R A C T
There is ongoing debate on whether stylolites act as barriers, conduits, or play no role in fluid transport. This problem can be tackled by examining the spatial and temporal relationships between stylolites and other diagenetic products at multiple scales. Using the well-known Lower Cretaceous Benicàssim case study area (Maestrat Basin, E. Spain), we provide new field and petrographic observations of how bedding-parallel stylolites can influence different diagenetic processes during basin evolution. The results reveal that stylolites can serve as baffles or inhibitors for different carbonate diagenetic reactions, and act as fronts for dolomitization, dolomite recrystallization and dolomite calcitization processes. Anastomosing stylolites that pre-date burial dolomitization probably acted as a collective baffle for dolomitization fluids in the study area, resulting in stratabound replacement geometries at the metre-to-kilometre scale. The dolomitization front coincides with stylolites, and can be traced along consecutive anastomosing ones. Such anastomosing stylolites are typical of mud-dominated facies that characterize limestone-dolostone transition zones. Conversely, dolostone bodies tend to correspond to more grain-dominated facies characterized by parallel (non-anastomosing) stylolites. Stylolites subsequently acted as fluid flow conduits and barriers when the burial and stress conditions changed. Stylolitic porosity enhanced by dissolution within dolostones close to faults appears filled with saddle dolomite riming the stylolite pore, and high-temperature blocky calcite cements filling the remaining porosity. The fluids responsible for these reactions were likely released from below at high pressure, causing hydraulic brecciation, and were channelised through stylolites, which acted as fluid conduits. Stylolites are also found acting as baffles for subsequent dolomite calcitization reactions during meteoric diagenesis and occasionally appear filled with iron oxides likely released by calcitization. This example demonstrates how the same type of stylolites (bedding-parallel) can act as barriers/inhibitors and/or conduits for different types of diagenetic reactions through time, and how important it is to consider their collective role when they form networks.
\end{abstract}

\section{Introduction}

Despite their simple mineralogy, carbonate rocks typically undergo heterogeneous post-depositional diagenesis that can significantly alter their original textures and petrophysical and mechanical properties.
Diagenetic processes like dissolution, cementation or mineral replacement are intimately linked to the diagenetic fluids that circulate through the pore space, and are therefore controlled by the available flow pathways and volume of fluid delivered to the reaction zone (Whitaker et al., 2004). In turn, the resulting diagenetic products impact the

\footnotetext{
* Corresponding author.

E-mail addresses: e.gomez-rivas@ub.edu (E. Gomez-Rivas), juandiegomartin@ub.edu (J.D. Martín-Martín), paul.bons@uni-tuebingen.de (P.D. Bons), daniel.

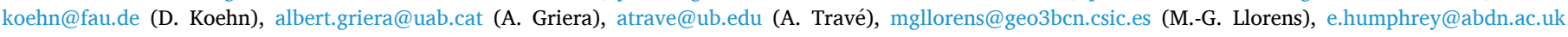
(E. Humphrey), j.neilson@abdn.ac.uk (J. Neilson).
} 
permeability and further reactivity of the evolving rock, creating highly complex feedback relationships that are challenging to decipher and predict. Understanding the factors that determine the distribution of diagenetic products is key for the study of the evolution of sedimentary basins and orogens, and also for predicting permeability anisotropy and reservoir quality (e.g., Moore, 2001; James and Jones, 2015). A wide range of studies have focused on the identification of the main controls on fluid flow in carbonate rocks and how they determine the distribution of diagenetic products (e.g., Agar and Hampson, 2014, and references therein). These studies include: (i) characteristics of the pores, which are controlled by the rock's depositional textures and diagenetic history, (ii) distribution and properties of fracture networks, (iii) type of pore fluids (marine, meteoric, basinal brines, etc.), their properties (temperature, pressure, salinity, etc.) and the forces that drive them to and from the reaction sites. However, less attention has been paid to stylolites as structures capable of partitioning fluid flow and creating permeability anisotropy that ultimately determines where, how and when diagenetic alterations take place.

Stylolites are usually rough dissolution surfaces that form during intergranular pressure-solution (e.g., Merino, 1992; Koehn et al., 2007; Toussaint et al., 2018). Bedding-parallel stylolites, also called diagenetic or sedimentary stylolites, form during burial and compaction as a response to layer-normal compression associated with the load of the overburden sediments. Stylolites are ubiquitous in most carbonate formations, present variable distributions depending on the host rocks (Ehrenberg et al., 2016) and often form complex anastomosing networks (Ben-Itzhak et al., 2014; Humphrey et al., 2020). These structures have historically been considered barriers to fluid flow across stylolites because they can collect insoluble material (e.g., clays, mica, oxides, sulphides, organic matter) while they grow (e.g., Nelson, 1981; Finkel and Wilkinson, 1990; Alsharhan and Sadd, 2000). Moreover, their growth can lead to a significant reduction of the overall porosity and permeability of the host rock because the dissolved mineral can re-precipitate nearby in the form of cement, thus controlling flow pathways for fluids that can induce further diagenetic reactions (Fabricius and Borre, 2007; Vandeginste and John, 2013). However, other studies have shown that fluids can also flow across stylolites (e.g., Neilson and Oxtoby, 2008; Morad et al., 2018), especially at their flanks and tips (Carozzi and von Bergen, 1987; Van Geet et al., 2001; Koehn et al., 2016; Humphrey et al., 2019). Stylolites can also be filled with cements, suggesting that fluids can be advected through them under certain conditions and precipitate minerals (Paganoni et al., 2016; Martín-Martín et al., 2018). Recently, laboratory permeability tests on core plugs have reported situations in which stylolites might not influence the overall vertical permeability of the rock in any way, because the measured permeability perpendicular to stylolites was the same as that in samples with no stylolites (Heap et al., 2014, 2018; Rustichelli et al., 2015). Furthermore, these authors also showed that stylolites can increase the overall rock permeability along the direction parallel to the stylolite plane. Koehn et al. (2016) proposed a new classification of stylolites in which their geometry and formation mechanisms determine whether they can be barriers to fluid flow or not. Bruna et al. (2019) recently reviewed the knowledge on how the formation and evolution of stylolites can define their behaviour with respect to fluid transport and cementation and concluded that further studies are required in order to fully understand the range of behaviour that these structures can present. In summary, deciphering the impact of stylolites on their host rock permeability is important to understand the flow of diagenetic and mineralizing fluids, and also for petroleum migration (e.g., Neilson et al., 1998; Baron and Parnell, 2007; Paganoni et al., 2016).

Within the framework of the ongoing debate on the impact of stylolites on fluid flow, it is critical that we can understand how these structures control the formation of other diagenetic products such as cements, replaced mineral phases and dissolution vugs. A key to constraining the influence of bedding-parallel stylolites on carbonate diagenesis is the careful examination of their spatial and temporal relationships with different diagenetic products at multiple scales. In this way three end-member scenarios can be proposed (Fig. 1). The first scenario considers that stylolites act as conduits for fluids and, therefore, the diagenetic reaction progresses from connected stylolites outwards (Fig. 1a). A second situation can arise when stylolite porosity and permeability are the same as those of the host rock and, therefore, they do not control fluid flow, and diagenetic reactions are not influenced by them (Fig. 1b). Finally, a third end-member case is one in which the diagenetic fluid cannot overcome stylolites so that the reaction is constrained to either side of the stylolite and, therefore, they act as reaction baffles (Fig. 1c). These scenarios assume that the diagenetic fluid can transport enough solutes to the reaction site, by advection-diffusion, and that the reaction will occur if the fluid reactivity and environmental conditions are appropriate. Finally, another hitherto key aspect not considered is that stylolites in nature often appear arranged in networks rather than in isolation (e.g., Ben-Itzhak et al., 2014; Humphrey et al., 2019; Humphrey et al., 2020). One should therefore evaluate how stylolites may collectively impact fluid flow, transport and reactions, and what the role of networks of stylolites is on these processes.

With the aim of tackling the questions above and improving our

\section{(a) Stylolites are conduits for diagenetic fluids}

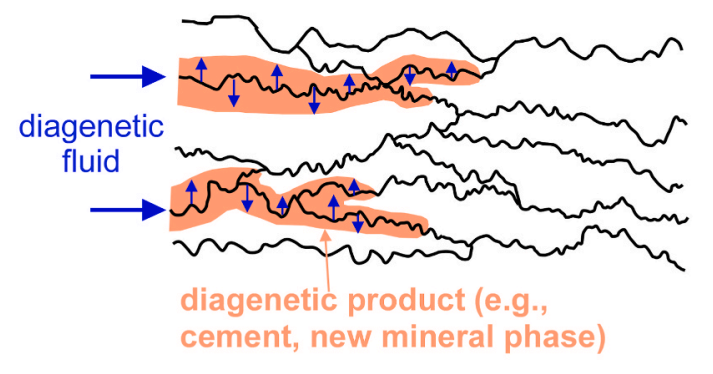

(b) Stylolites are neither fluid conduits nor baffles

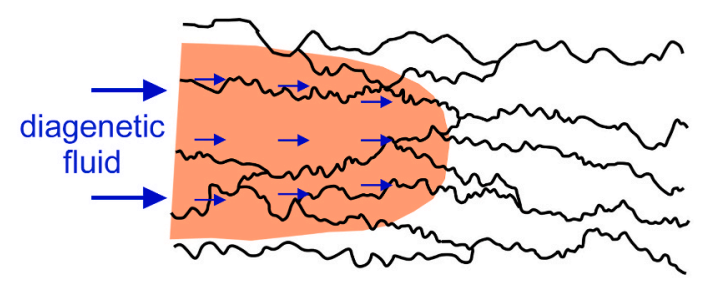

(c) Stylolites are baffles for diagenetic fluids

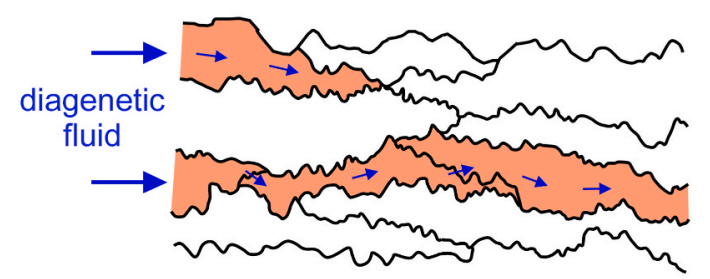

Fig. 1. Sketches illustrating end-member scenarios of the potential control of stylolites on diagenetic fluid flow and reaction patterns. (a) Stylolites are more permeable than their host rocks and act as conduits for diagenetic fluids. In such cases the reaction progresses from the stylolites outwards, and the diagenetic product initially forms a halo. (b) Stylolites have the same transport properties as those of the host rock and therefore do not control flow and reactions. In such a situation the reaction front is not influenced by them. (c) Stylolites act as barriers for the diagenetic fluid and reaction, and therefore constrain the diagenetic product to one of their sides. The capacity of the fluid to overcome an individual stylolite or not may depend on the stylolite morphology and its sealing properties. 
understanding of the controls that stylolites exert on fluid flow, transport and diagenetic reactions, we present and discuss examples from shallow-marine Upper Aptian-lowermost Albian carbonates of the Benassal Formation (Fm) in the Benicàssim area (Maestrat Basin, E. Spain). We examine mineral replacement reactions (dolomitization and dolomite calcitization) at multiple scales, dolomite recrystallization, dissolution, and precipitation of saddle dolomite, calcite and iron oxide cements. Building upon the extensive previous knowledge of the area (Martín-Martín et al., 2013, 2015, 2018; Gomez-Rivas et al., 2014; Humphrey et al., 2020; Yao et al., 2020), we provide new observations and analyses of outcrops and samples to decipher (i) whether individual stylolites act as baffles/inhibitors or enhancers of different types of diagenetic reactions, (ii) whether the same structures can exhibit different transport behaviour and, finally, (iii) to what extent large-scale diagenetic alterations (i.e., with dimensions of metres to kilometres) can be controlled by stylolite networks.

\section{Geological setting}

The Early Cretaceous Benicàssim carbonate platform (Maestrat Basin, E. Spain) (Fig. 2a and b) constitutes a world-class example of synrift shallow-marine carbonate deposition (Salas et al., 2001) and fault-controlled hydrothermal dolomitization (Yao et al., 2020). In this area, a $>1600$ m-thick succession of syn-rift shallow-marine Upper Aptian-lowermost Albian limestones of the Benassal Fm was partially dolomitized as a result of the flow of warm brines that were advected from the underlying sedimentary and basement rocks along large-scale faults, which acted as feeders for dolomitizing and subsequent mineralizing fluids (Fig. 2c; Martín-Martín et al., 2013; Gomez-Rivas et al., 2014; Martín-Martín et al., 2015, 2018; Yao et al., 2020). The host rock succession, which is stacked in three transgressive-regressive sequences, underwent a complex diagenetic history (Fig. 2c; Fig. 3), including mechanical compaction, early calcite and dolomite cementation, chemical compaction, two phases of replacive dolomitization, burial dissolution, local brecciation (in the vicinity of faults), calcite cementation, sulphide mineralization and, finally, calcitization of dolomite as well as late meteoric calcite cementation (see Martín-Martín et al., 2015 for a complete description of the paragenesis). The first dolomitization phase (RD1) mimicked the original limestone texture while the second dolomite phase (RD2) formed by recrystallization of RD1.

\section{Previous work}

Field and petrographic observations show that bedding-parallel stylolites formed soon after deposition during the early diagenetic stages in close association with the Early Cretaceous rifting. In this regard, chemical compaction by stylolitization predated dolomite cementation and replacive dolomitization stages (Martín-Martín et al., 2015, 2018) (Fig. 2b). Humphrey et al. (2020) investigated the prevalence of the different stylolite types in the most representative carbonate depositional facies of the Benassal Fm, using the classification of Koehn et al. (2016). Suture-and-sharp peak and wave-like stylolites are ubiquitous in all the facies analyzed, with grainstones also featuring rectangular layer-type stylolites (Fig. 4). Facies with relatively homogeneous components, such as bioclastic and ooidal/peloidal grainstones, tend to present parallel (i.e., non-anastomosing) stylolites with large spacings and low amplitudes (Fig. 4a and b). Stylolites in mud-supported facies, with heterogeneous grain compositions, poor sorting and meter-scale bedding, typically have high amplitudes, they are normally closely spaced and tend to form anastomosing networks (Fig. 4c and d).

Burial curves indicate that dolomitization took place at depths of less than $1 \mathrm{~km}$ during the Late Cretaceous post-rift period (Fig. 2c). The dolomitizing fluid was a seawater-derived brine that interacted and exchanged with the underlying Permian-Triassic and Paleozoic basement rocks (Gomez-Rivas et al., 2014). Post-replacement cements include burial calcite cement filling intercrystalline porosity, and hydrothermal saddle dolomite and blocky calcite cements in the vicinity of faults (Martín-Martín et al., 2018). Dolomite calcitization released Fe from the dolostones and was caused by the circulation of meteoric fluids, which took place more intensively in areas close to major faults (Martín-Martín et al., 2015). The Benicàssim and equivalent rocks in the Maestrat Basin host Mississippi Valley Type metal sulphide deposits that were dated by U-Pb at $62.6 \pm 0.7 \mathrm{Ma}$ by Grandia et al. (2000). Moreover, two events of Alpine deformation were identified from fracture and vein networks in the area, with a first strike-slip event with WSW-ENE-oriented horizontal compression and a second oblique-slip event with SW-NE-oriented principal compressive stress (Gomez-Rivas et al., 2012).

Dolostones in the Benicàssim area crop out as seismic-scale geobodies with geometries ranging from massive patches around large-scale faults, which were interpreted to have acted as entry points of dolomitizing fluids, to very well-defined stratabound geobodies that extend for long distances away from them (Yao et al., 2020). The dolomitized stratabound units in the studied outcrops have thicknesses of up to 150 $\mathrm{m}$ (Fig. 5a) and replace limestones that were deposited mostly during the regressive cycles of the two uppermost transgressive-regressive sequences of the Benassal Fm (see Yao et al., 2020 for a detailed study of the relationships between sequence stratigraphy and dolomitization).

\section{Methods}

Expanding upon extensive research on the Benicàssim area, we have carefully mapped and examined diagenetic replacement fronts at variable scales, ranging from the $\mathrm{km}$-to the $\mu \mathrm{m}$-scale, away from large-scale faults and within the stratigraphic and structural context. We have reexamined more than 300 thin sections analyzed in previous studies ( $e$. g., Martín-Martín et al., 2013, 2015, 2018; Gomez-Rivas et al., 2014; Humphrey et al., 2020, Yao et al., 2020). Moreover, 20 additional samples of selected reaction fronts were collected for a detailed characterization of such surfaces. Samples were collected with a portable drill, to acquire cylinders with a diameter of 1". Double-polished thin sections were made from those samples. Details of stylolites and diagenetic reaction fronts were systematically studied with standard petrographic and cathodoluminescence microscopy, the latter with a Technosyn Cold Cathode Luminescence model 8200 MkII, with operating conditions of $15-18 \mathrm{kV}$ and gun current of 300-350 A. Thin sections of existing and new samples were carbon-coated for their study using an ISI ABT-55 Scanning Electron Microscope (SEM) at $15 \mathrm{kV}$ at the University of Aberdeen.

Stylolites were classified according to Koehn et al. (2016). The term wave-like stylolites also includes the so-called wispy seams and pressure-solution seams (with peak amplitude $<1 \mathrm{~cm}$ ) of Alsharhan and Sadd (2000). Depositional textures of the limestones are defined using the scheme of Dunham (1962), including modifications by Embry and Klovan (1971).

\section{Results}

The field analysis of diagenetic reaction fronts cropping out in the Benicàssim area where dolostone geobodies are stratabound revealed that bedding-parallel stylolites commonly form dolomitization fronts, and thus define the contact between dolostones and host limestones (Figs. 5 and 6). Less frequently, stylolites appear separating the two dolomite textures RD1 and RD2 (Fig. 6) or form the interface between dolomite and calcitized dolomite (Fig. 7). Additionally, stylolites are in some specific cases found open, with the stylolitic porosity partly enhanced by dissolution and filled with saddle dolomite and calcite cements and, in some other cases, with iron oxides (Fig. 8). In this section we describe the characteristics of the relationships between stylolites and five types of diagenetic reactions: dolomitization, dolomite recrystallization, dissolution, cementation and dolomite calcitization. 

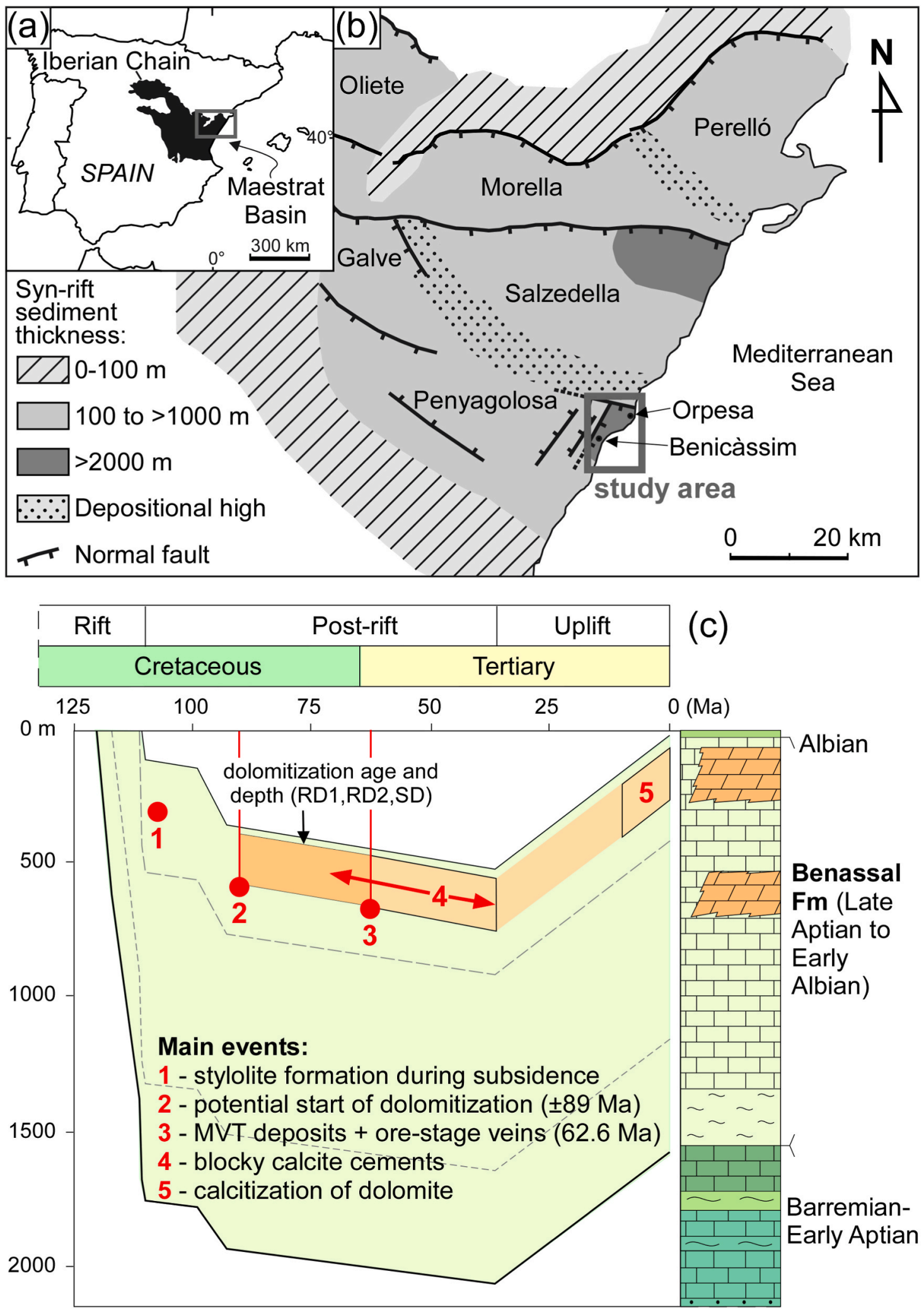

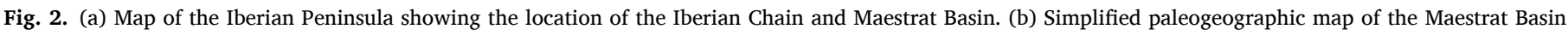

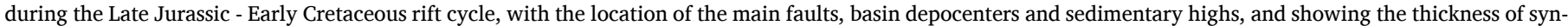

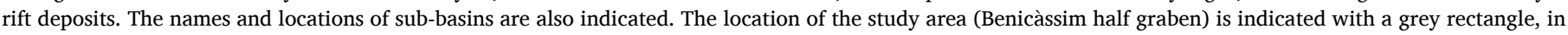

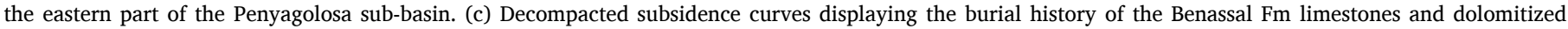

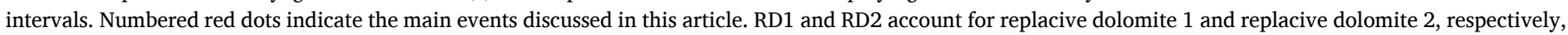

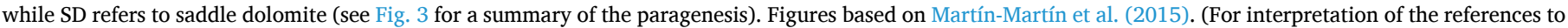
colour in this figure legend, the reader is referred to the Web version of this article.) 
Mechanical compaction

Marine cements

Bedding-parallel stylolites

Replacive dolomite (RD1)

Replacive dolomite (RD2)

Corrosion

Saddle dolomite

Blocky calcite cements

Ore-stage calcite

MVT-type ore deposits

Calcitization (dedolomitization)

\& Fe oxide precipitation

Meteoric calcite cement \& veins

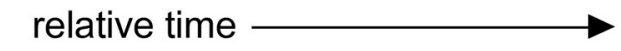

$113 \mathrm{Ma}$

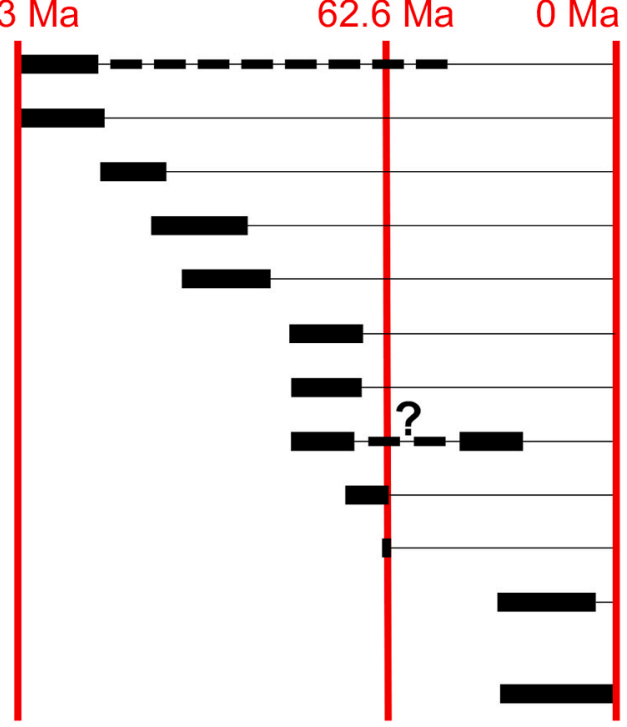

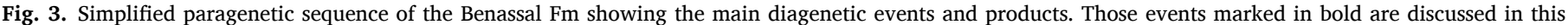

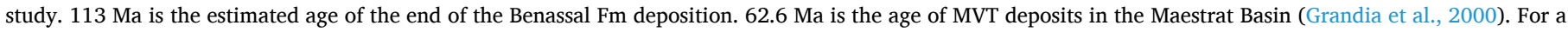
complete description of the paragenesis see Martín-Martín et al. (2015) and Martín-Martín et al. (2018).
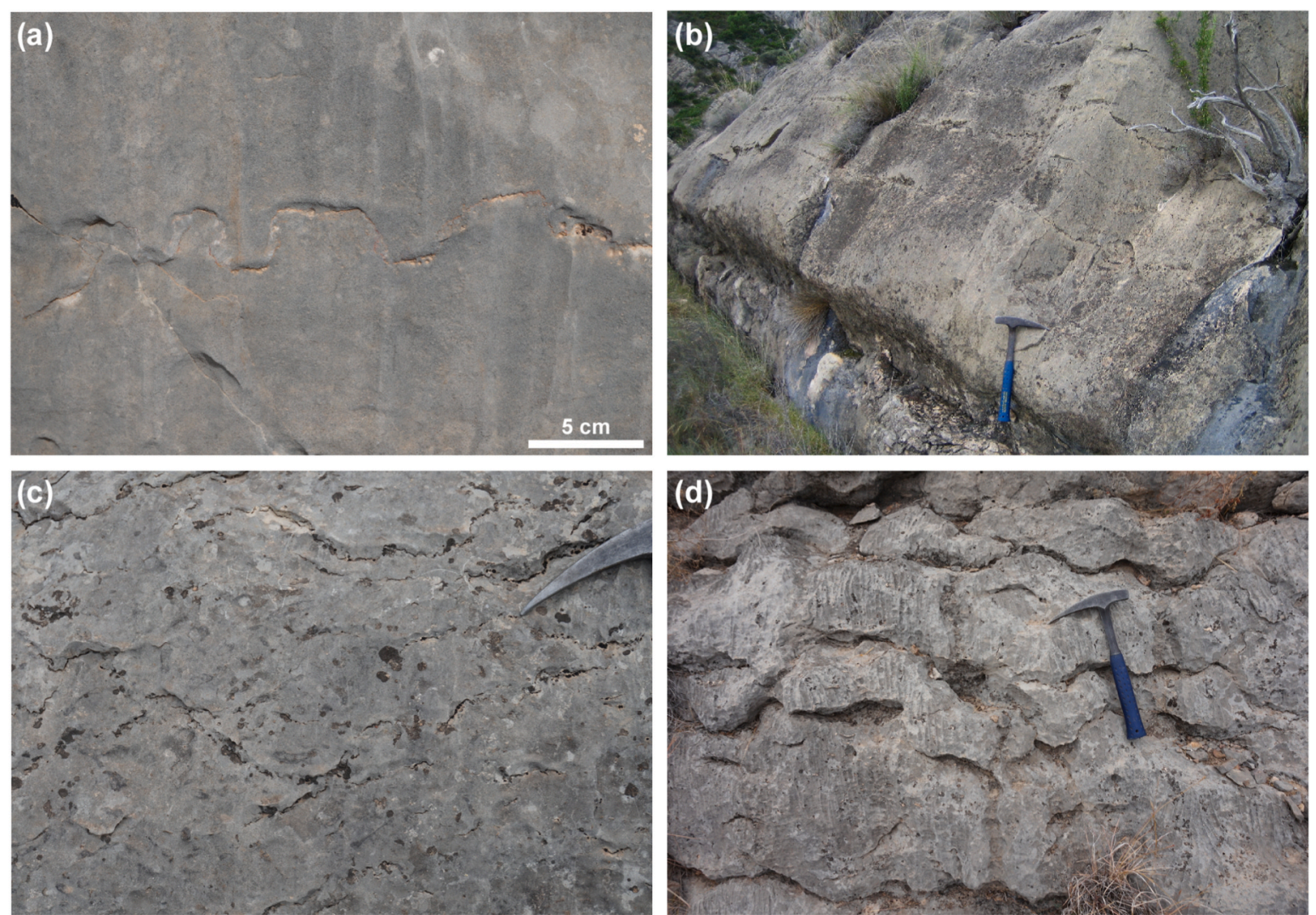

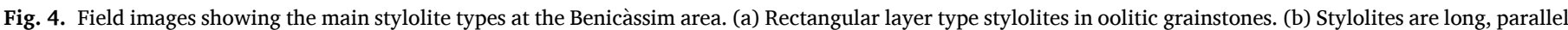

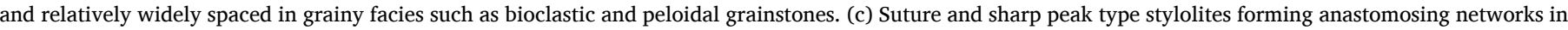

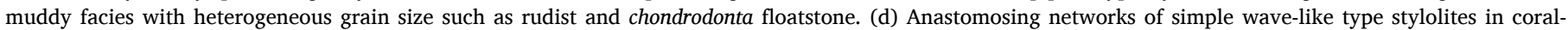
line facies.

A close look at the outcrops away from faults reveals that dolomitization fronts are always extremely sharp at the centimetre to metre scale, parallel to bedding and very frequently coincide with suture-and- sharp peak and wave-like stylolites (Fig. 5b-d). The statistical analysis by Humphrey et al. (2020) of stylolite morphology and their statistical distributions revealed that dolomitized units tend to have stylolite 

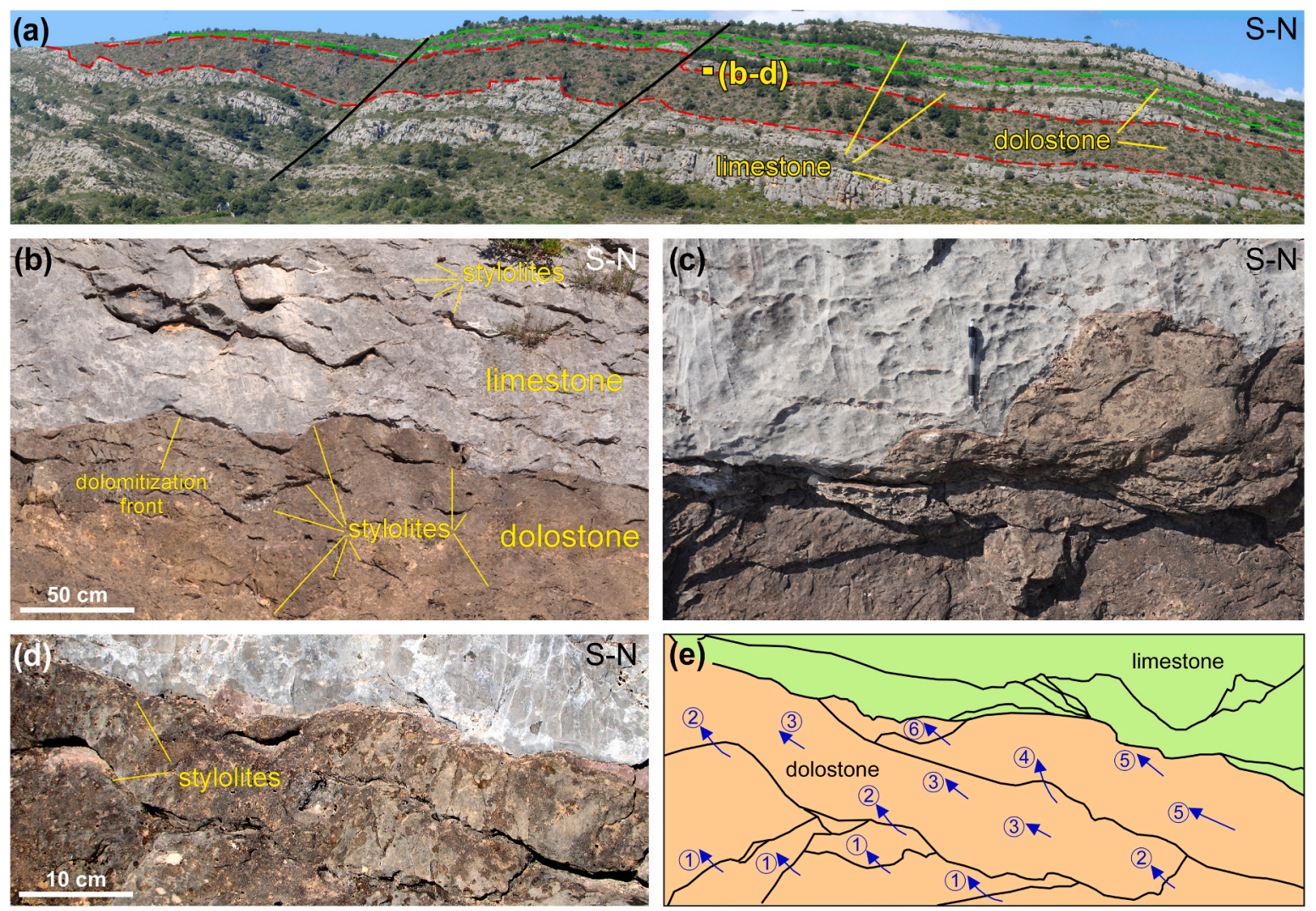

Fig. 5. Outcrop images of stylolites acting as dolomitization fronts at the Benicàssim area. (a) Panoramic view of the Racó del Moro outcrop (Yao et al., 2020), where dolostone geobodies present a stratabound geometry, and dolomitized layers extend for several km away from large-scale faults. The two main dolostone bodies are indicated. The location of photos (b-d) is indicated on the panorama. (b-d) Zooming into dolomitization fronts. A pervasive network of bedding-parallel suture-and-sharp peak and wave-like stylolites can be observed both in the limestones and dolostones. The dolomitization front weaves up and down following consecutive stylolites. (e) Interpretation of image (d), where limestone is represented in green, dolostone in orange and arrows with numbers that represent the progressive flow of dolomitizing fluids. Each number (1-6) represents a sequential step of the reactive fluid overcoming the barrier of one stylolite and dolomitizing the rock volume constrained by the next reaction barrier (stylolite). Please note that in this outcrop the dolomitizing fluid is interpreted to have flowed from the north, as suggested by Yao et al. (2020). (For interpretation of the references to colour in this figure legend, the reader is referred to the Web version of this article.)

distributions similar to those of relatively homogeneous non-dolomitized grainy facies (e.g., bioclastic and ooidal/peloidal packstones and grainstones). However, limestones with anastomosing networks of stylolites, which are typically poorly sorted and mud-rich, frequently bound sets of dolomitized beds. In such cases, anastomosing stylolites coincide with dolomitization fronts (Fig. 5b-d).

Field observations in the areas where dolostones are stratabound indicate that the dolomitization fronts weave up and down following consecutive stylolites (Fig. 5b-c), and this is especially evident in facies in which stylolites form anastomosing networks and merge with or abut each other. Stylolite networks in such situations typically show the same geometry and distribution on both sides of the dolomitization front, so that these fronts do not necessarily coincide with bed surfaces or boundaries between different types of facies (Fig. 5b). On the contrary, fronts are embedded within the same poorly sorted and mud-rich facies.

The observation of dolomitization fronts at the microscale revealed that suture-and-sharp-peak and wave-like stylolites, as well as the reaction fronts associated with them, are not sharp and discrete at the scale of millimetres but have a width of up to a few tens of microns (Fig. 6). Fig. 6a-c shows an illustrative example of a reaction front bounded by a series of stylolites. In the central part of this micrograph, the dolomitization front is limited by an up to $100 \mu \mathrm{m}$ wide single pressure-solution zone (Fig. 6d). However, laterally two other stylolites bound the front resulting in a partial dolomitization of the rock volume between the two consecutive stylolites (Fig. 6b-c). Pressure-solution zones corresponding to stylolites that are visible at the outcrop and thin section scale are not discrete surfaces at the microscale but have a certain width. These zones present a relatively high concentration of iron oxides (Fig. 6d) with some scarce clay minerals, mostly illite, as observed using SEM analysis. However, a massive and continuous residue at the pressure solution zone cannot be observed in the Benicàssim stylolites. The absence of a systematic and continuous stylolite residue is consistent with the lack of clastic components in the $>1600 \mathrm{~m}$ thick Benassal Fm sediments (Yao et al., 2020).

Thin sections show that stylolites also appear separating the two different types of replacive dolomite, RD1 and RD2, previously reported by Martín-Martín et al. (2015) (Figs. 3 and 6a,g). RD1 pervasively replaced micrite, skeletal and non-skeletal grains as well as pre-dolomitization calcite cements, causing a mimetic replacement that did not significantly alter the original porosity and permeability of the limestone. RD2 replaced RD1 in the most permeable areas resulting in non-mimetic, medium to coarse planar-s to non-planar-a crystal mosaics with higher porosity and permeability than RD1 dolomite. The main differences between RD1 and RD2 are the larger crystal size of the latter, and that RD2 crystals have RD1 core and clear edges. SEM examination of stylolites within dolostone reveals that stylolites pre-date dolomite crystal formation, because dolomite crystals systematically overprint stylolites (Fig. 6e,h-i). In thin sections these stylolites are observed to separate RD1 and RD2 crystals mosaics, suggesting that stylolites acted as recrystallization fronts (Fig. $6 \mathrm{~g}$ ). All the stylolites of Fig. $6 \mathrm{~g}$ belong to the same anastomosing network, where the relative angle they form with each is a sectioning effect. Distinguishing between RD1 and RD2 at outcrops is difficult, and their differentiation is mainly based on thin section analysis. This implies that it is not possible to systematically 

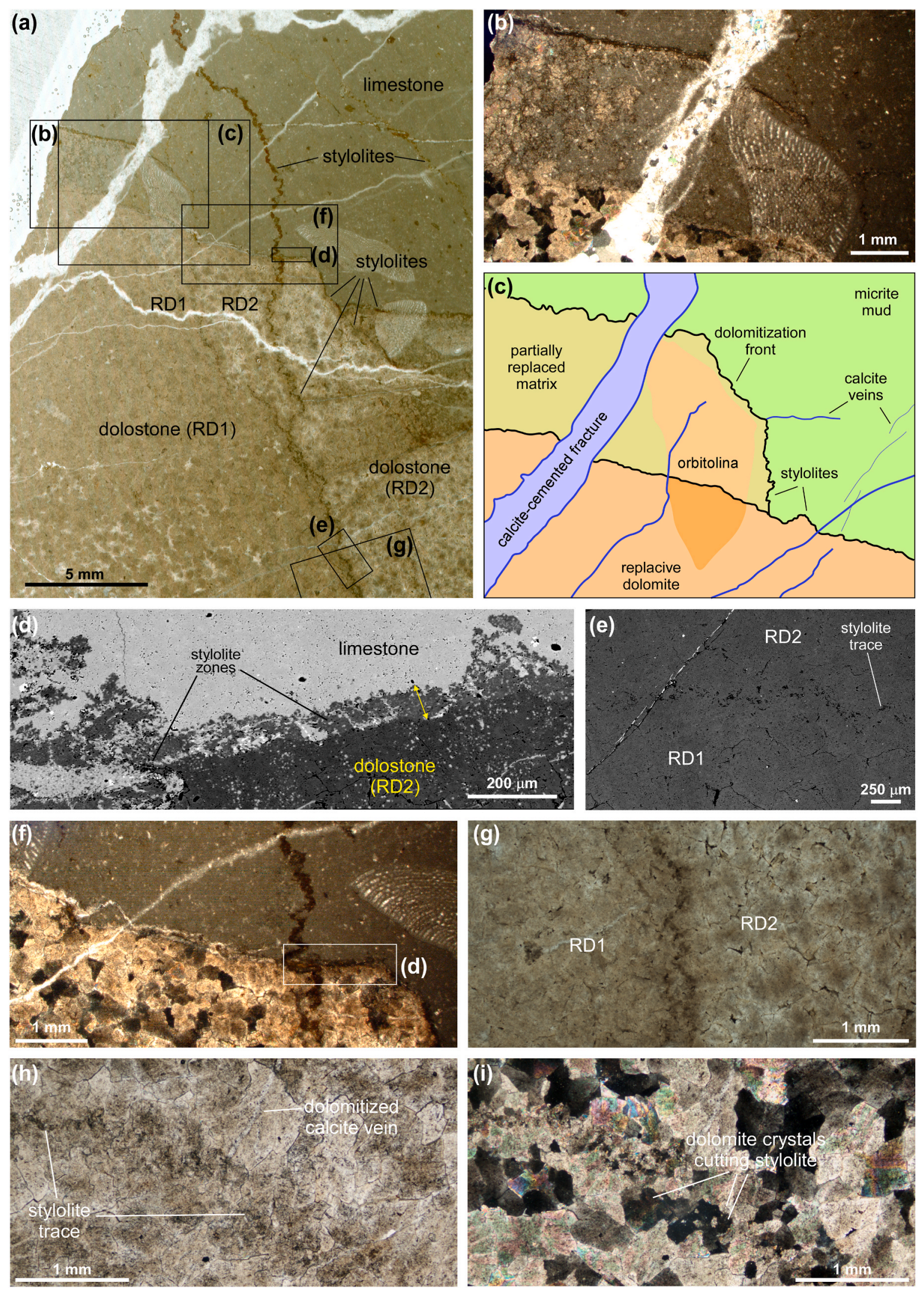

(caption on next page) 


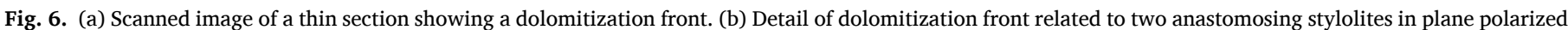

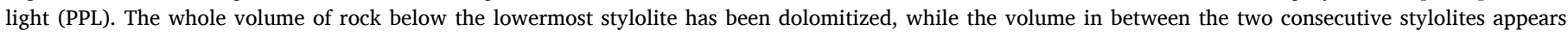

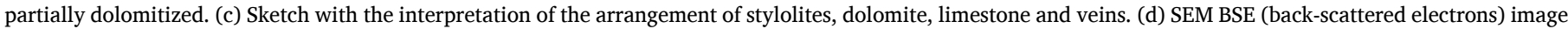

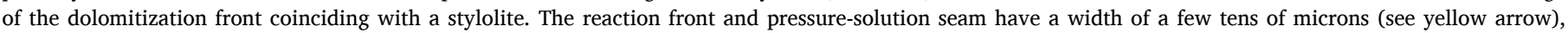

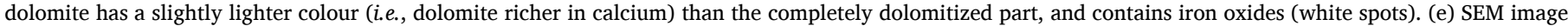

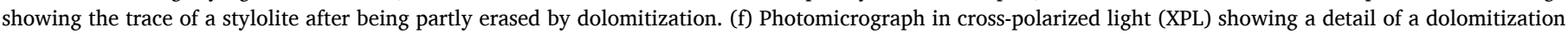

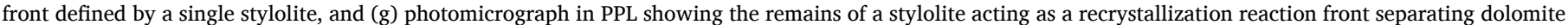

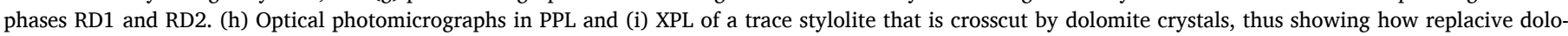

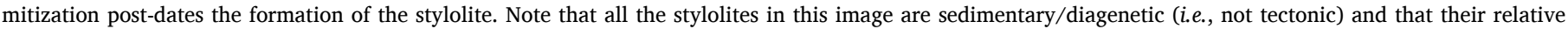

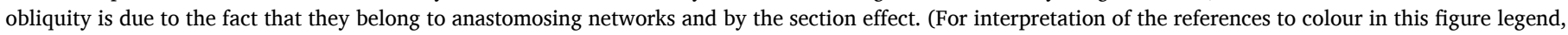
the reader is referred to the Web version of this article.)
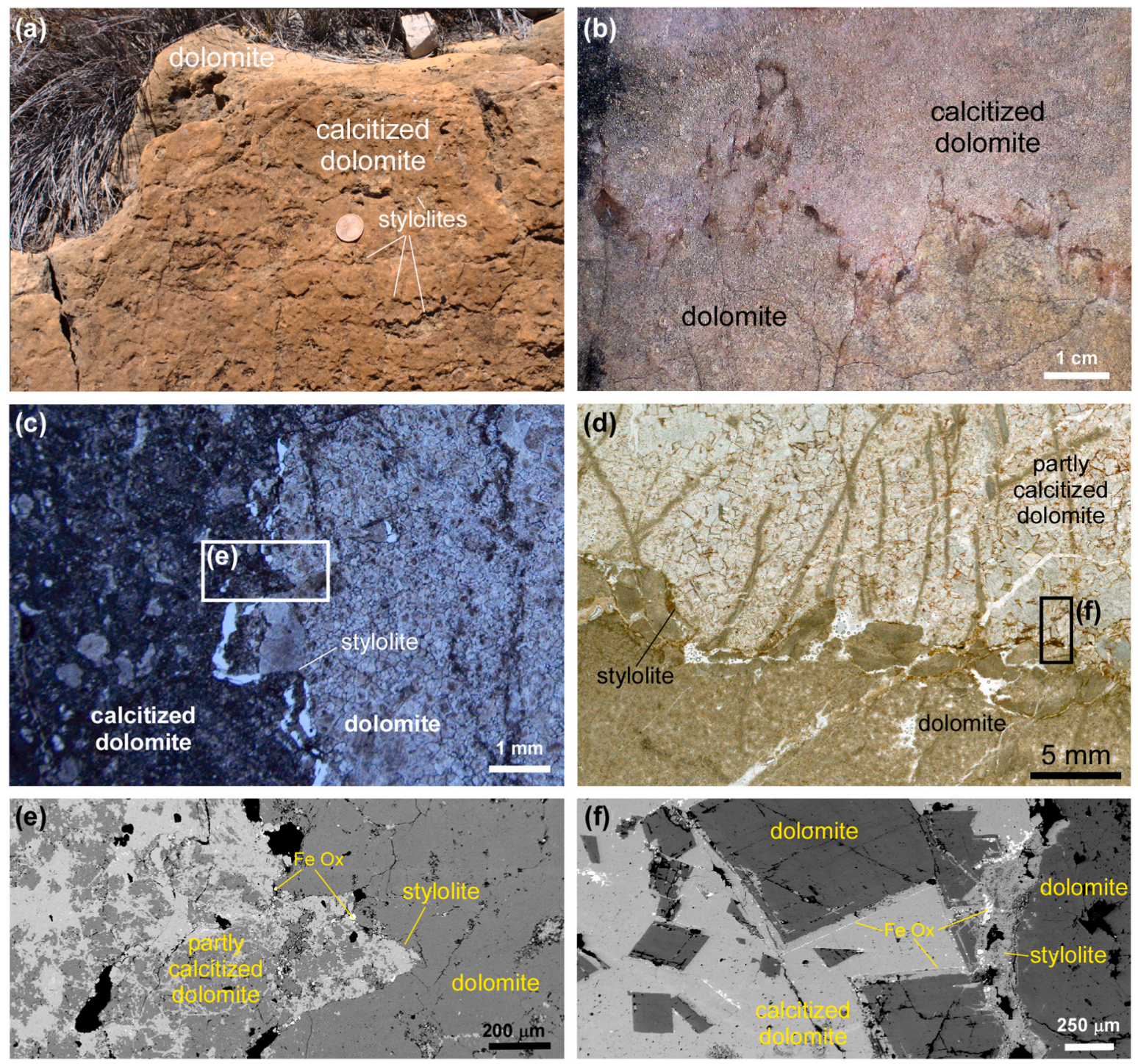

Fig. 7. (a-b) Outcrop images of dolomite calcitization (i.e., dedolomitization). fronts. (a) Note the different aspect of dolomite and calcitized dolomite. The orange tone reveals the presence of iron oxides, while less altered dolomite is brown. (b) A rectangular stylolite separating calcitized from unaltered dolomite. (c) Optical photomicrograph (PPL) and (d) scanned thin section showing calcitization fronts coinciding with stylolites and vertical dolomite relicts of microfractures. (e) BSE image of area in (c) showing a detail of a stylolite acting as a calcitization front. (f) BSE image of area in (d) showing a detail of dolomite rhomb dissolution resulting in the precipitation of iron oxides (labelled as Fe Ox) around them. In (e) and (f) dolomite is dark grey while calcite is seen as light grey. The dolomite calcitization process is associated with the formation of a relatively large volume of Fe oxides (Fe Ox, in white) and the creation of porosity (in black). (For interpretation of the references to colour in this figure legend, the reader is referred to the Web version of this article.)

evaluate and quantify the lateral extent and frequency of stylolites acting as recrystallization fronts.

A relatively high proportion of the Benicàssim dolostones appears calcitized (i.e., dedolomitized) in the volume of rock near outcrop surfaces and in the vicinity of faults (Martín-Martín et al., 2015) (Fig. 7).
This calcitization is associated with the formation of Fe oxides that give the characteristic brown/orange colour of dolostones on outcrop surfaces (Fig. 7a and b). Bedding-parallel stylolites can also be found coinciding with dolomite calcitization fronts, so that the calcitization reaction only affected (or mostly affected) the rock volume on one side 

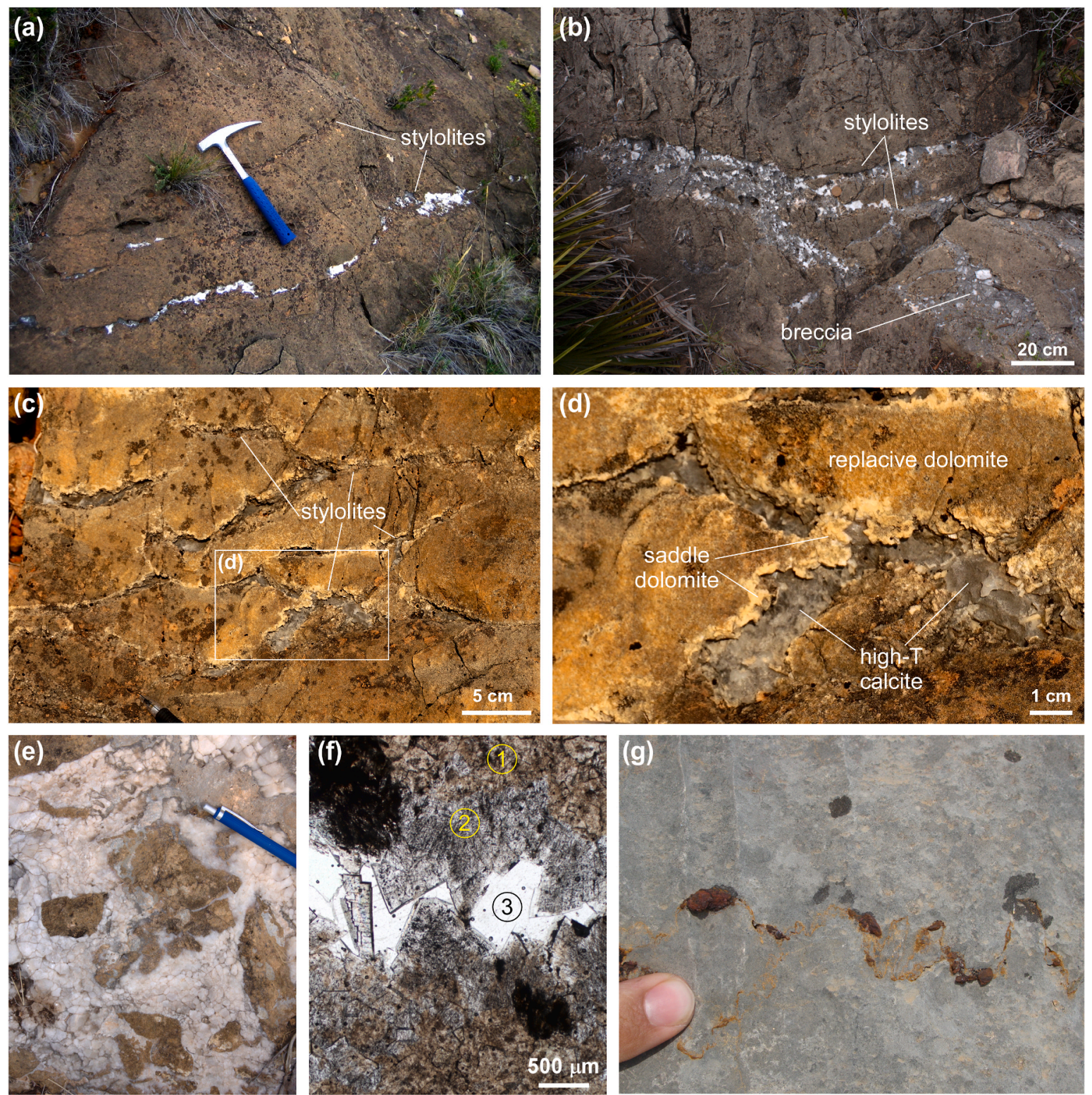

Fig. 8. Examples of stylolites acting as conduits for diagenetic fluids. (a-e) Stylolites filled with saddle dolomite and high-temperature calcite. (a) Cemented wavelike stylolites. (b-c) Anastomosing stylolite networks filled with saddle dolomite and calcite cements. Note brecciation within stylolites in (b). (d) Detail of (c), where the host rock around stylolites is partly dissolved and stylolite porosity is filled with a rim of saddle dolomite while the remaining porosity is filled with hightemperature calcite cement. (e) Close view of a hydraulic breccia of high-temperature calcite cements that engulf host rock replacive dolostone and saddle dolomite clasts. (f) Photomicrograph of a stylolite showing signs of dissolution of the replacive dolomite (1), saddle dolomite rimming the stylolite porosity (2) that is filled with white calcite crystals (3). (g) Stylolitic porosity filled with iron oxides that probably resulted from dolomite calcitization.

of the stylolite. The Benicàssim dolostones have a variable but relatively high amount of Fe (up to 28,600 ppm; Martín-Martín et al., 2015), and when dolomite is calcitized this Fe is not incorporated in the structure of the newly formed calcite crystals but is released to form Fe oxides (Fig. 7c, e). Moreover, the flow of meteoric fluids, likely subsaturated with respect to dolomite, resulted in the formation of irregularly distributed vuggy porosity. Both Fe oxides and newly formed pore space can be identified in hand specimen, and by optical and SEM petrography (Fig. 7e and f). Fe oxides can be found within stylolites (Fig. 8g).

Contrary to dolomitization, the processes of dolomite recrystallization and dolomite calcitization are more heterogeneously distributed and difficult to be spatially characterized. Therefore, unlike the case of dolomitization, the systematic quantification of the relationships between stylolites and the processes of dolomite recrystallization and dolomite calcitization from outcrop studies would require the collection of a very large number of core plugs that would damage the outcrops too much.

Bedding-parallel stylolitic porosity in the Benicàssim dolostones is also found filled with saddle dolomite and calcite cements, which were interpreted to have formed from hydrothermal fluids (Martín-Martín et al., 2018, Fig. 8a-f). The replacive dolomite appears partly dissolved in the proximity of one to $10 \mathrm{~m}$-scale faults, such as those shown in Fig. 5a. That dissolution process appears to not affect limestones. Dolostones contain elongated vuggy pores that follow stylolites (Fig. 8a-d,f). These dissolution features have a width of millimetres to centimetres, and can sometimes be up to about $2 \mathrm{~m}$ long. These type of dissolution pores are aligned parallel to bedding planes and concentrate along stylolites of the same types as those forming dolomitization fronts. Stylolitic pores are generally filled with saddle dolomite cements that rim the pores formed by dissolution (Fig. 8d,f). These cements typically 
have a white to pale yellowish colour and millimetre crystal size and are composed of mosaics of blade-shaped non-planar dolomite crystals. The remaining porosity left by the saddle dolomite cement rims is filled with coarse subhedral blocky calcite cement characterized by coarse and white to pale orange crystals. This cement commonly engulfs fragments of the host dolostone and saddle dolomite (Fig. 8e) and can be found in contact with etched margins of replacive dolomite and/or saddle dolomite crystals indicating that host rock dissolution preceded its precipitation. Partly dissolved stylolites filled with these cements, and related to brecciation, typically branch away from faults (Fig. 8b).

\section{Discussion}

6.1. Stylolites and stylolite networks as diagenetic reaction baffles/ inhibitors

The Benicàssim case study demonstrates how individual stylolites and anastomosing networks of stylolites can act as vertical (and sometimes also lateral) baffles for successive diagenetic reactions (Fig. 9). This section discusses several aspects of this relationship from their timing to the role of stylolites as baffles for dolomitization, dolomite recrystallization and dolomite calcitization reactions at multiple scales.

\subsubsection{Relative timing of stylolite formation versus dolomitization}

The statistical analysis of stylolite types and their distributions presented in Humphrey et al. (2020) shows how the vast majority of stylolites in the Benicàssim area are of the suture-and-sharp peak and wave-like type. Both types of stylolites grow in a non-linear fashion, present a low roughness and can potentially collect insoluble material (Koehn et al., 2016). Therefore, according to the morphology and formation conditions of these two stylolite types (i.e., absence of pinning structures and rare straight teeth), they should have a relatively high sealing potential compared to the other stylolite types (i.e., rectangular layer and seismogram pinning). These observations corroborate results
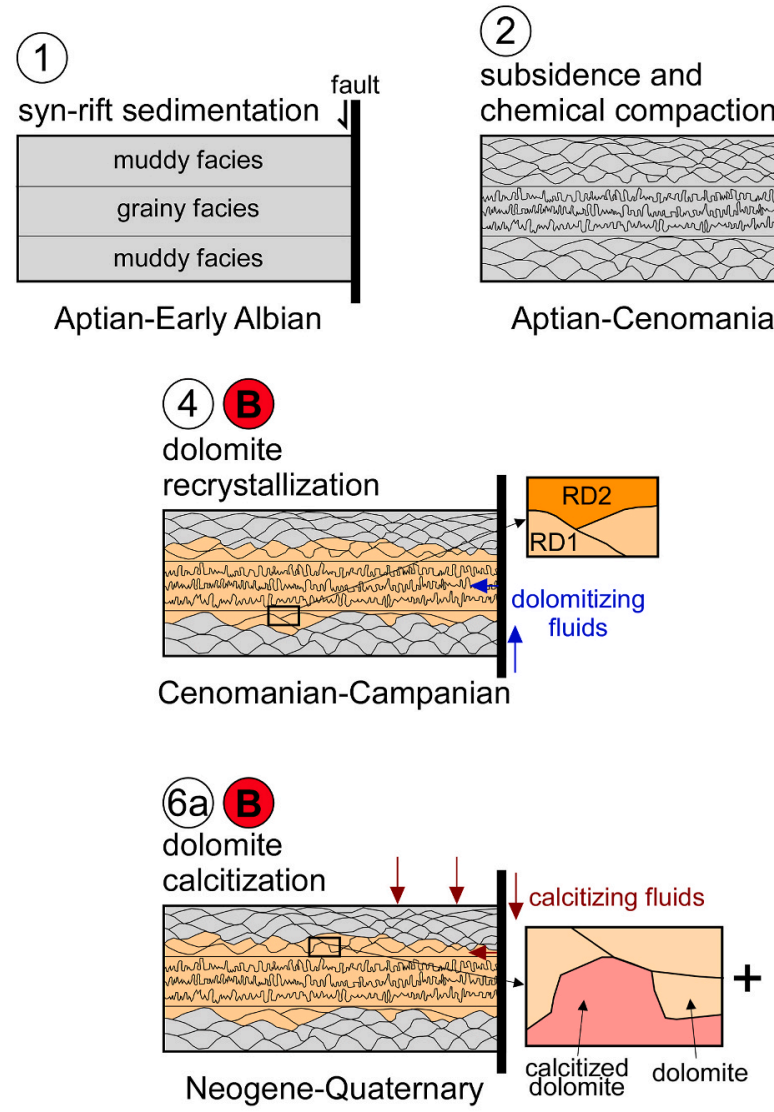

(2) subsidence and chemical compaction

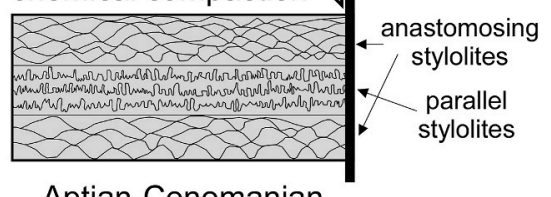

Aptian-Cenomanian

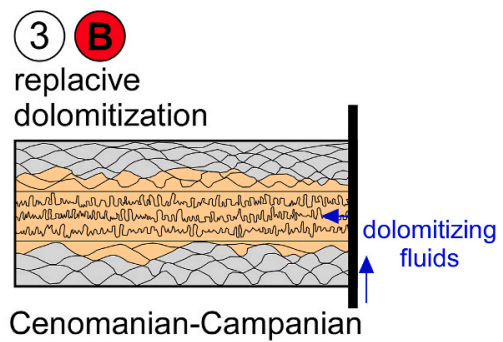

(5) (C) stylolite aperture, dissolution, cementation of hydrothermal carbonates (saddle dolomite and calcite)
Paleocene-Oligocene
fault

(6b) (C) iron oxide

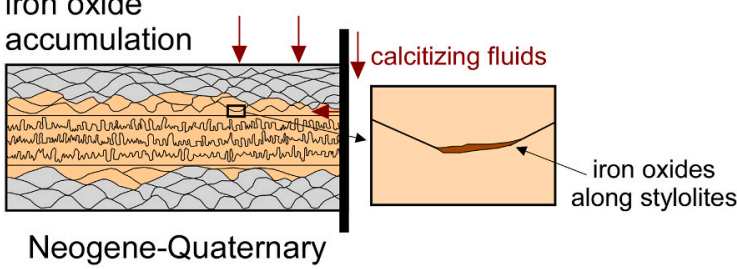

(B) Stylolites act as reaction baffles

(C) Stylolites act as conduits for fluids

Fig. 9. Synthetic sketches showing the relationships between stylolites and diagenetic processes during the geological evolution of the Benicàssim area. (1) Limestones were deposited during the Aptian-Early Albian syn-rift period. (2) Subsidence caused chemical compaction, resulting in the formation of networks of stylolites with various morphologies and distributions. In general, grainy facies feature relatively non-anastomosing bedding-parallel stylolites, while muddy facies tend to have more anastomosing stylolite networks (for the full statistical analysis see Humphrey et al., 2020). (3) Replacive dolomitization during the Late Cretaceous post-rift stage was controlled by the sedimentary facies and the presence of networks of stylolites, which acted as baffles for the replacement reaction at the outcrop scale. The dolomitization front weaves up and down following consecutive anastomosing stylolites. (4) Some stylolites acted as baffles for dolomite recrystallization reactions at the local scale, separating two phases of replacive dolostones (RD1 and RD2) with different texture and geochemical signature. (5) At some stage between the Paleocene and the Oligocene some bedding-parallel stylolites within dolostones close to faults were opened, and overpressured fluids flowed along them causing partial dissolution, growth of saddle dolomite and high-temperature calcite cement, and hydraulic brecciation. (6) The Benicàssim dolostones were partly calcitized at outcrop surfaces and fault zones by meteoric fluids from the Neogene to the Quaternary, and some stylolites also acted locally as baffles for dolomite calcitization reactions. Stylolites are also occasionally found filled with iron oxides resulting from their accumulation during the calcitization reaction. (B) and $(C)$ refer to stages in which stylolites have acted as barriers/baffles and conduits for diagenetic fluids and reactions. 
of drill core sample studies by Vandeginste and John (2013) from the Canterbury Basin (offshore New Zealand).

At Benicàssim, stylolite dolomitization fronts frequently occur in facies where stylolites form anastomosing networks (i.e., in mud-rich beds; Fig. 4b), while most of the dolostone volume replaced grainy facies units with a certain amount of mud and parallel stylolites (Fig. 9). This point is supported by the following observations: (i) dolomitized rocks tend to feature stylolite distributions similar to those of the wellsorted grainy facies (i.e., bioclastic and ooidal/peloidal packstones and grainstones), and (ii) the systematic petrographic analysis of dolostones shows that such type of grainy facies is preferentially dolomitized (Martín-Martín et al., 2015). Stylolite roughening tends to be favoured in grainy facies because the quenched noise of grains triggers the pinning process (e.g., see Koehn et al., 2007; Koehn et al., 2012). Accordingly, stylolites in grainy facies tend to accommodate dissolution by roughening, while strain in muddy facies can be preferentially accommodated by forming new seams instead of roughening the existing ones. Therefore, spacing of bedding-parallel stylolites is typically smaller in mud-dominated facies, favouring the formation of anastomosing networks. Anastomosis is also promoted by the cannibalization of pre-existing stylolites, a process that is also enhanced in lithofacies with grain size heterogeneity and poor sorting (Ben-Itzhak et al., 2014). At the large (half-graben) scale dolostones dominantly replace grainy limestone facies. However, stylolites control the dolomitization fronts at the outcrop scale. The presence of anastomosing stylolites in dolomitization front zones compared with the non-anastomosing character of stylolites in most dolostones can explain why the dolomitization reaction stopped at these levels and did not progress further to upper or lower strata (Fig. 9). The dolomitization fluid could invade the host limestones corresponding to facies with non-anastomosing stylolites but would be stopped in rock containing anastomosing stylolite networks that would have collectively acted as reaction baffles. This can be explained by the weaving of the reaction fronts up and down and by the stylolite distribution being very similar in the proximity of the observed fronts and on both of the front sides (see Fig. 6). Fluid flow cannot easily bypass anastomosing stylolites, as they abut on other stylolites thus inhibiting fluids infiltrating laterally. Dewit et al. (2014) described high-temperature dolostone bodies bounded by a unit of thick-bedded bioclastic wackestone alternating with nodular limestone beds. They interpreted that this massive limestone acted as an impermeable unit and that dolomitizing fluids could only overcome it by flowing through faults. In our case, wackestones and nodular limestones also bound dolostone, but the stylolites they host actually control the replacement reaction front locally.

\subsubsection{Stylolites and anastomosing stylolite networks as dolomitization reaction baffles}

The fact that anastomosing stylolites acted as collective baffles to the dolomitization fluids reveals that it is the network of stylolites rather than individual ones that constrain the dolomitization reaction to one side of them by channelling fluid flow parallel to layering. Apart from the lithological control (muddy versus grainy facies), this phenomenon explains the stratabound character of the replacement reaction, as observed in many case studies of hydrothermal dolomitization (e.g., see Davies and Smith, 2006; Dewit et al., 2014). An individual stylolite by itself may not be able to constrain the diagenetic fluid, but the ensemble of partial fluid baffles in the form of a network of connected stylolites would constitute an efficient diagenetic fluid baffle. In such a scenario, a stylolite-bound volume of rock would be invaded by the diagenetic fluid that induces the replacement reaction. When the fluid overcomes the barrier of an individual stylolite, it will invade the whole the rock volume enclosed by the neighbouring stylolite, as indicated by the sequence of arrows in Fig. 5e. This mechanism of overcoming (or not) consecutive flow baffles explains why replacement is constrained by stylolites and why the front weaves up and down following them. Evidence supporting the role of anastomosing stylolites in constraining the reaction front is that such stylolite networks typically show a similar geometry and distribution in the vicinity of the front and on both sides of it (Fig. 5b). The strong continuity and lateral extension of networks of suture-and-sharp peak and wave-like stylolites contribute to the marked stratabound character of dolostone geobodies in the eastern side of the Benicàssim half graben, where they extend laterally for at least $7 \mathrm{~km}$ away from the feeding faults. A similar case of kilometre-scale continuity of stylolite networks was described by Ben-Itzhak et al. (2012) in northern Israel.

The role of stylolites as dolomitization reaction baffles observed in outcrop becomes more complex at the small scale. Petrographic observations from optical and SEM show how reaction fronts enforce a certain width. This width can range from a few tens of microns when the front is formed by a single stylolite (Fig. $6 \mathrm{f}$ ) to a few millimetres when it is constrained by two consecutive stylolites (Fig. 6b). However, individual stylolites tend to be more discrete planes when found either in limestone or dolostone, but become a more diffuse pressure-solution zone when they coincide with the dolomitization front, forming a transition zone in which both calcite and dolomite crystals can be found (Fig. 6b,d).

Similar observations of stylolites bounding dolostones were described by Narkiewicz (1979) in a case study of hydrothermal dolomitization of Upper Devonian carbonates from Southern Poland. This author suggested that stylolites, especially horse tail ones (i.e., wave like), formed a barrier to dolomitization, and that stylolites within limestones contain dispersed dolomite rhombohedra. Narkiewicz (1979) also described how in certain cases the replacement front is gradual over a few centimetres, a feature that we have also observed at the petrographic (mm) scale. Miller and Folk (1994) also described stylolite-controlled burial dolomitization of the uppermost Triassic Portoro Limestone of Liguria (Italy). These authors interpreted that dolomitization fluids were fed by faults and then were buffered in their proximity. They also observed dolostones systematically bounded by bedding-parallel (wispy) stylolites, which clearly pre-date dolomitization, as in our case study. Miller and Folk (1994) also observed partial dolomitization in between two consecutive stylolites, in a way that one stylolite could not constrain the reaction, but the following stylolite could halt it. This represents another example in which the stylolite network rather than individual stylolites controlled the progress of the replacement reaction. Thus, the case studies of Narkiewicz (1979) and Miller and Folk (1994) share very similar characteristics with the Benicàssim outcrops, in terms of the dolomitization mechanism, type of stylolites and arrangement of dolomitization fronts with regard to stylolite networks.

The stylolites analyzed with SEM in this study do not contain a continuous insoluble residue (Fe oxides and clay minerals). Accordingly, it is not the presence of impermeable insoluble minerals that stops the flow of the dolomitization fluid, or at least it is not the only mechanism. Instead, there should be a different mechanism to explain why the dolomitization reaction can be constrained by stylolites. A potential explanation is that dolomitization can be constrained when it reaches a surface in which the characteristics of carbonate grains are different. Differences can be a consequence of local variations in mineral composition of the carbonate components (e.g., high-Mg calcite or low$\mathrm{Mg}$ calcite), different reactive surface area or surface energy when there are partially dissolved crystal facets (e.g., Hadjittofis et al., 2021), and the presence of small amounts of insoluble material. In such a scenario a rough surface resulting from chemical dissolution can potentially act as a baffle and not allow the reaction front to progress, without the need of a continuous volume of insoluble and impermeable residue.

The progressive lateral jump of the dolomitization front up and down between neighbouring stylolites reveals that a single stylolite may not act as an insurmountable barrier to transport, but the statistical combination of multiple barriers in the form of a connected stylolite network can stop a diagenetic reaction. The overall distribution of stylolites can define anisotropy of permeability at the metre to kilometre scale, and thus result in anisotropy of advective transport (Fig. 9). Additionally, the merging or cannibalization of stylolites during the formation of 
anastomosing networks can enhance the porosity heterogeneity and can also help explain to their role as dolomitization reaction baffles. This process can enhance the concentration of insoluble material where pressure solution is focused on anastomosing stylolite zones within mudrich limestones. In such situations stylolites are not only baffles to vertical fluid flow but also to horizontal transport. Peacock et al. (2017) demonstrate by means of numerical models how the progressive addition and interaction of stylolites during the progressive formation of bedding-parallel stylolite networks can result in porosity heterogeneity, in a way that porosity can be lower close to stylolites and higher away from them.

\subsubsection{Stylolites as dolomite recrystallization and dolomite calcitization reaction baffles}

Examples of stylolites separating two dolomite textures have also been found in the Benicàssim area (see Fig. 6). This indicates that pressure-solution structures also acted as baffles for diagenetic fluids producing recrystallization at the small scale (Fig. 9). RD2 crystals have a slightly depleted oxygen isotopic composition compared to RD1, and this was interpreted to result from a higher temperature fluid (Allan and Wiggins, 1993; Martín-Martín et al., 2015). Compared to dolomitization, the process of dolomite recrystallization is heterogeneous and its lateral and vertical extent is difficult to quantify in the field.

The role of stylolites as dolomite calcitization reaction baffles is not as systematic as that of dolomitization fluid flow barriers, because the process of synchronous dolomite dissolution and calcite precipitation is normally widespread and heterogeneous, according to the literature (e. g., see review article by Schoenherr et al., 2018 and references therein). This is also the case for calcitization in the Benicàssim area, where it has been interpreted as related to the infiltration of meteoric water and therefore restricted to subaerially exposed rock volumes (Martín-Martín et al., 2015). Calcitization in the Benicàssim area is associated with dolomite dissolution because this process resulted in a texture change with the calcitized dolomite having a cavernous texture (with millimetre-sized cavities), as previously described by Ayora et al. (1998), and occasionally coarse grained. A close look at dolomite calcitization fronts at the microscale indicates that this process is progressive, as revealed by the strong variability in its intensity depending on the sample chosen or even within the same sample (Fig. 7). The presence of stylolites acting as barriers to dolomite calcitization fluids has also been reported in studies of mudstones of the Zechstein Ca2 Stassfurt carbonate of the Southern Permian Basin in NW Germany (Koehn et al., 2016; Schoenherr et al., 2018; Humphrey et al., 2019). Although the extent and distribution of dolomite recrystallization and calcitization products are difficult to quantify, the Benicàssim case study demonstrates that stylolites can act as barriers for these fluids. Geochemical and reactive transport models suggest that dolomite calcitization is a relatively slow diagenetic reaction, which takes tens to thousands of years to partly replace significant rock volumes (Escorcia et al., 2013). In such a scenario, stylolites can control the permeability of the calcitizing rock and thus locally determine the distribution of the resulting product (Fig. 9).

\subsection{Stylolites as diagenetic fluid flow conduits}

Stylolitic porosity in the study area is filled with saddle dolomite and blocky calcite cements (Fig. 8), indicating that some stylolites were open at some stage and acted as conduits for the fluids (Fig. 9). Cemented stylolite porosity is only found within dolostones (i.e., not in nonreplaced limestones) and in the proximity of faults. Field and petrographic observations indicate that stylolitic porosity was enhanced by dissolution, and later cemented first by saddle dolomite, which rims the stylolitic pore space, and then by blocky calcite cement. Therefore, this cemented secondary porosity is extremely localized and overall has a very limited volume (e.g., that of the dolostone and burial calcite cements filling such stylolitic porosity). Martín-Martín et al. (2018) studied these cements and concluded that both resulted from the flow of high-temperature brines. Moreover, hydraulic brecciation took place synchronously with cementation because clasts of replacive dolostone and saddle dolomite are engulfed by blocky calcite crystals (Fig. 8e). This type of brecciation (Jébrak, 1997) indicates that fluids were overpressured. The processes of dissolution, saddle dolomite cementation, hydraulic brecciation and blocky calcite cementation probably took place a long time after dolomitization, either during the early Paleocene ore deposit formation event or during the Alpine compression stage (Eocene to mid Oligocene; Salas et al., 2001). As explained in section 3, the Alpine orogeny in the study area is characterized by the presence of calcite veins and occasional tectonic stylolites that formed because of horizontal to subhorizontal compression during two different stages (Gomez-Rivas et al., 2012). Following the model of Staude et al. (2009), the circulation of hot fluids would have been triggered by a reduction of the overburden pressure, while horizontal to subhorizontal compression could have contributed to the opening of stylolites next to faults. In such a scenario hot and overpressured fluids would flow through these structures causing dissolution, brecciation and cementation (Martín-Martín et al., 2018). Some of these stylolites belong to the same network as those bounding dolomitization fronts. Accordingly, stylolites can exhibit a dual behaviour, first acting as baffles and later as conduits for diagenetic fluids, depending on the burial conditions and the characteristics of the diagenetic fluids.

The role of stylolites as conduits for diagenetic fluids in diverse diagenetic settings has been documented in the literature. Stacey et al. (2021) described low-amplitude stylolites cross-cutting (and thus post-dating) four phases of hydrothermal replacive dolomite in the Middle Cambrian Cathedral Fm of the Western Canadian Sedimentary Basin, and how they are filled with a late dolomite cement. As in the case of Benicàssim, these authors relate this cement to hydraulic breccias related to fluid volume expansion. Barnett et al. (2015) observed stylolites acting as conduits for mesogenetic corrosive fluids, as well as for the formation of secondary microporosity offshore Mumbai (India). Chandra et al. (2014) also observed dissolution associated with transport along stylolites in a giant Paleogene reservoir. They describe how stylolites and related tension gashes were opened during tectonic uplift and served as conduits for reactive fluids that dissolved the host rock and delivered sulphides, silica and aluminium. As in the Benicàssim case study, they also suggest that such fluids could have been fed by faults. Olierook et al. (2014) described a case study in which stylolites contain halos of quartz cements and are sealed in fault zones. Braithwaite (1989) proposed fluid overpressure as a key mechanism to enhance permeability along stylolites, while Paganoni et al. (2016) reported a case study in an Abu Dhabi hydrocarbon reservoir where hot brines and oil migrated along stylolites during horizontal compression. They found that such brines resulted in precipitation of carbonates, clays and other minerals around stylolites, changing their role from conduits during brine flow to their present-day behaviour as barriers to vertical fluid flow. The Benicàssim case of stylolites acting as conduits for high-temperature overpressured fluids shares key similarities with all these studies, showing how a change of burial, stress and fluid pressure conditions can switch their impact on permeability and thus on diagenetic reaction patterns.

The present study shows an integrated example of how stylolites and stylolite networks can control the distribution of diagenetic reactions from the millimetre to the metre and even kilometre scales. The successive dual behaviour of stylolites and stylolite networks at Benicàssim as baffles and conduits for fluids depending on the burial and stress conditions, as well as the host rock characteristics, is summarized in Fig. 9. Understanding this dual behaviour has key implications not only to unravel the diagenetic history of an area, but also in terms of societal challenges. Stylolites can play a role in petroleum migration and entrapment systems (Dunnington, 1954; Ehrenberg et al., 2016), ore deposit distribution (Tucker, 2015; Humphrey et al., 2019) and can also potentially control mineral reactions in geothermal reservoirs or $\mathrm{CO}_{2}$ 
storage sites. This contribution reveals how the presence of insoluble material is not the only control on the transport behaviour of stylolites, but how studying networks of stylolites is as important as analysing individual ones. Further systematic work is required to fully understand how these structures determine fluid migration and mineral reactions.

\section{Conclusions}

The main conclusions of this study are:

1. Individual stylolites can act as baffles/inhibitors for different types of diagenetic carbonate reactions. We report examples of stylolites acting as fronts for dolomitization, dolomite recrystallization and dolomite calcitization reactions.

2. Networks of anastomosing bedding-parallel stylolites, rather than individual stylolites, can control the geometries and extent of largescale, metre- to kilometre-scale diagenetic alterations, such as dolomitization. The replacive dolomitization reaction at Benicàssim was controlled by stylolite networks in a way that the stratabound dolomitization front weaves up and down following consecutive anastomosing stylolites depending on whether the reactive fluid could or could not overcome the baffles formed by stylolites. The anastomosing network acted as a collective baffle in mud-dominated limestone facies, preventing them from undergoing replacement by dolomite. In contrast, most dolostone units have parallel and nonanastomosing stylolite networks, which correspond mostly to limestones dominated by grainy facies.

3. Stylolites acting as diagenetic reaction barriers lack a continuous seam of insoluble material at the microscale, and are normally a few tens to hundreds of microns wide. Their role as reaction baffles/inhibitors must then be due to their different reactive surface area or slight variations in carbonate mineral composition compared to the reacting limestone components.

4. Some of the same stylolites that were baffles to fluids subsequently acted as fluid conduits when the tectonic stress, burial conditions and/or fluid pressure changed. At Benicàssim, stylolites within dolostones close to faults are partly dissolved and filled with saddle dolomite riming the stylolite pore and high-temperature blocky calcite filling most of the remaining porosity. The fluids responsible for these reactions are interpreted to have been released at high pressure, also causing hydraulic brecciation. Stylolites are also found filled with iron oxides resulting from the dolomite calcitization process associated with meteoric fluids.

\section{Declaration of competing interest}

The authors declare that they have no known competing financial interests or personal relationships that could have appeared to influence the work reported in this paper.

\section{Acknowledgments}

This research was carried out within the framework of the Spanish Ministry of Science and Innovation Projects PGC2018-093903-B-C22 and PID2020-118999GB-I00, the Grup Consolidat de Recerca "Geologia Sedimentària" (2017-SGR- 824, funded by the Agency for Management of University and Research Grants, Catalan government, Spain) and the DGMK (German Society for Petroleum and Coal Science and Technology) project 718, funded by the companies ExxonMobil Production Deutschland GmbH, GDF SUEZ E\&P Deutschland GmbH, RWE Dea AG, and Wintershall Holding GmbH. EGR acknowledges funding by the Spanish Ministry of Science, Innovation and Universities ("Ramón y Cajal" fellowship RYC2018-026335-I), and the Geological Society of London Elspeth Matthews Fund 2015 grant. MGL acknowledges funding by the Spanish Ministry of Science, Innovation and Universities ("Juan de la Cierva-Incorporación" fellowship IJC2018-036826-I). We thank associate editor Marco Brandano and reviewers Marco Antonellini and Sadoon Morad for their valuable suggestions, which have significantly improved this article.

\section{References}

Agar, S.M., Hampson, G.J., 2014. Fundamental controls on flow in carbonates: an introduction. Petrol. Geosci. 20, 3-5. https://doi.org/10.1144/petgeo2013-090.

Allan, J.R., Wiggins, W.D., 1993. Dolomite reservoirs: geochemical techniques for evaluating origin and distribution. Am. Assoc. Pet. Geol. Contin. Educ. Course Notes 36 (Tulsa).

Alsharhan, A., Sadd, J.L., 2000. Stylolites in Lower Cretaceous Carbonate Reservoirs, vol. 69. U.A.E. Society for Sedimentary Geology Special Publication, pp. 185-207. https://doi.org/10.2110/pec.00.69.0185.

Ayora, C., Taberner, C., Saaltink, M.W., Carrera, J., 1998. The genesis of dedolomites: a discussion based on reactive transport modeling. J. Hydrol. 209, 346-365.

Barnett, A.J., Wright, V.P., Chandra, V.S., Jain, V., 2015. Distinguishing between eogenetic, unconformity-related and mesogenetic dissolution: a case study from the Panna and Mukta fields, offshore Mumbai, India. Geol. Soc. Lond. Spec. Publ. 435 (1), 67-84. https://doi.org/10.1144/SP435.12.

Baron, M., Parnell, J., 2007. Relationships between stylolites and cementation in sandstone reservoirs: examples from the north Sea, U.K. And East Greenland. Sediment. Geol. 194, 17-35. https://doi.org/10.1016/j.sedgeo.2006.04.007.

Ben-Itzhak, L., Aharonov, E., Toussaint, R., Sagy, A., 2012. Upper bound on stylolite roughness as indicator for amount of dissolution. Earth Planet Sci. Lett. 337-338, 186-196. https://doi.org/10.1016/j.epsl.2012.05.026.

Ben-Itzhak, L., Aharonov, E., Karcz, Z., Kaduri, M., Toussaint, R., 2014. Sedimentary stylolite networks and connectivity in Limestone: large-scale field observations and implications for structure evolution. J. Struct. Geol. 63, 106-123. https://doi.org/ 10.1016/j.jsg.2014.02.010.

Braithwaite, C.J.R., 1989. Stylolites as open fluid conduits. Mar. Petrol. Geol. 6 (1), 93-96. https://doi.org/10.1016/0264-8172(89)90078-0.

Bruna, P.O., Lavenu, A.P., Matonti, C., Bertotti, G., 2019. Are stylolites fluid-flow efficient features? J. Struct. Geol. 125, 270-277. https://doi.org/10.1016/j. jsg.2018.05.018.

Carozzi, A.V., von Bergen, D., 1987. Stylolitic porosity in carbonates: a critical factor for deep hydrocarbon production. J. Petrol. Geol. 10, 267-282. https://doi.org/ 10.1111/j.1747-5457.1987.tb00946.x.

Chandra, V., Wright, P., Barnett, A., Steele, R., Milroy, P., Corbett, P., Geiger, S., Mangione, A., 2014. Evaluating the impact of a late-burial corrosion model on reservoir permeability and performance in a mature carbonate field using nearwellbore upscaling. Geol. Soc. Lond. Spec. Publ. 406 (1), 427-445. https://doi.org/ 10.1144/SP406.11.

Davies, G.R., Smith, L.B.J., 2006. Structurally controlled hydrothermal dolomite reservoir facies: an overview. AAPG (Am. Assoc. Pet. Geol.) Bull. 90, 1641-1690. https://doi.org/10.1306/05220605164.

Dewit, J., Foubert, A., El Desouky, H.A., Muchez, P., Hunt, D., Vanhaecke, F., Swennen, R., 2014. Characteristics, genesis and parameters controlling the development of a large stratabound HTD body at Matienzo (Ramales Platform, Basque-Cantabrian Basin, northern Spain). Mar. Petrol. Geol. 25, 6-25. https://doi. org/10.1016/j.marpetgeo.2013.12.021.

Dunham, R.J., 1962. Classification of carbonate rocks according to depositional textures. In: Ham, W.E. (Ed.), Classification of Carbonate Rocks - a Symposium. Mem. 1. American Association of Petroleum Geologists, Tulsa, OK, pp. 108-121.

Dunnington, H.V., 1954. Stylolite development post-dates rock induration. J. Sediment. Petrol. 24, 27-49.

Ehrenberg, S.N., Morad, S., Yaxin, L., Chen, R., 2016. Stylolites and porosity in a lower Cretaceous limestone reservoir, onshore Abu Dhabi, UAE. J. Sediment. Res. 86 (10), 1228-1247. https://doi.org/10.2110/jsr.2016.68.

Embry, A.F., Klovan, J.E., 1971. A late Devonian reef tract on northeastern Banks Island, N.W.T. Bull. Can. Petrol. Geol. 19, 730-781. https://doi.org/10.35767/ gscpgbull.19.4.730.

Escorcia, L., Gomez-Rivas, E., Daniele, L., Corbella, M., 2013. Dedolomitization and reservoir quality, insights from reactive transport modelling. Geofluids 13 (2), 221-231. https://doi.org/10.1111/gfl.12023.

Fabricius, I.L., Borre, M.K., 2007. Stylolites, porosity, depositional texture, and silicates in chalk facies sediments. Ontong Java Plateau: gorm and Tyra fields, North Sea. Sedimentology 54, 183-205. https://doi.org/10.1111/j.1365-3091.2006.00828.x.

Finkel, E.A., Wilkinson, B.H., 1990. Stylolitization as source of cement in Mississippian Salem limestone, west-central Indiana. AAPG (Am. Assoc. Pet. Geol.) Bull. 74, 174-186. https://doi.org/10.1306/0C9B2295-1710-11D7-8645000102C1865D.

Gomez-Rivas, E., Warber, K., Kulzer, F., Bons, P.D., Koehn, D., Martín-Martín, J.D., 2012. Structural evolution of the Benicàssim area (Maestrat basin, NE Spain): insights from fracture and vein analysis. Geogaceta 51, 79-82.

Gomez-Rivas, E., Corbella, M., Martín-Martín, J.D., Stafford, S.L., Teixell, A., Bons, P.D., Griera, A., Cardellach, E., 2014. Reactivity of dolomitizing fluids and Mg source evaluation of fault-controlled dolomitization at the Benicàssim outcrop analogue (Maestrat Basin, E Spain). Mar. Petrol. Geol. 55, 26-42. https://doi.org/10.1016/j. marpetgeo.2013.12.015.

Grandia, F., Asmerom, Y., Getty, S., Cardellach, E., Canals, A., 2000. U-Pb dating of MVT ore-stage calcite: implications for fluid flow in a Mesozoic extensional basin from Iberian Peninsula. J. Geochem. Explor. 69-70, 377-380. https://doi.org/10.1016/ S0375-6742(00)00030-3. 
Hadjittofis, E., Vargas, S.M., Litster, J.D., Sedransk Campbell, K.L., 2021. The role of surface energy in the apparent solubility of two different calcite crystal habits. Proc. Math. Phys. Eng. Sci. 477, 2252 https://doi.org/10.1098/rspa.2021.0200.

Heap, M.J., Baud, P., Reuschle, T., Meredith, P.G., 2014. Stylolites in limestones: barriers to fluid flow? Geology 42 (1), 51-54. https://doi.org/10.1130/G34900.1.

Heap, M., Reuschlé, T., Baud, P., Renard, F., Iezzi, G., 2018. The permeability of stylolitebearing limestone. J. Struct. Geol. 116, 81-93. https://doi.org/10.1016/j. jsg.2018.08.007.

Humphrey, E., Gomez-Rivas, E., Koehn, D., Bons, P.D., Neilson, J., Martín-Martín, J.D., Schoenherr, J., 2019. Stylolite-controlled diagenesis of a mudstone carbonate reservoir: a case study from the Zechstein-2-Carbonate (Central European Basin, NW Germany). Mar. Petrol. Geol. 109, 88-107. https://doi.org/10.1016/j. marpetgeo.2019.05.040.

Humphrey, E., Gomez-Rivas, E., Neilson, J., Martín-Martín, J.D., Healy, D., Yao, S., Bons, P.D., 2020. Quantitative analysis of stylolite networks in different platform carbonate facies. Mar. Petrol. Geol. 114, 104203 https://doi.org/10.1016/j. marpetgeo.2019.104203.

James, N.P., Jones, B., 2015. Origin of Carbonate Sedimentary Rocks. Wiley, 464.

Jébrak, M., 1997. Hydrothermal breccias in vein-type ore deposits: a review of mechanisms, morphology and size distribution. Ore Geol. Rev. 12, 111-134. https:// doi.org/10.1016/S0169-1368(97)00009-7.

Koehn, D., Renard, F., Toussaint, R., Passchier, C.W., 2007. Growth of stylolite teeth pattern depending on normal stress and finite compaction. Earth Planet Sci. Lett. 257, 582-595. https://doi.org/10.1016/j.epsl.2007.03.015.

Koehn, D., Ebner, M., Renard, F., Toussaint, R., Passchier, C.W., 2012. Modelling of stylolite geometries and stress scaling. Earth Planet Sci. Lett. 341-344, 104-113. https://doi.org/10.1016/j.epsl.2012.04.046.

Koehn, D., Rood, M.P., Beaudoin, N., Chung, P., Bons, P.D., Gomez-Rivas, E., 2016. A new stylolite classification scheme to estimate compaction and local permeability variations. Sediment. Geol. 346, 60-71. https://doi.org/10.1016/j. sedgeo.2016.10.007.

Martín-Martín, J.D., Gomez-Rivas, E., Bover-Arnal, T., Travé, A., Salas, R., MorenoBedmar, J.A., Tomás, S., Corbella, M., Teixell, A., Vergès, J., Stafford, S.L., 2013. The Upper Aptian to Lower Albian syn-rift carbonate succession of the southern Maestrat Basin (Spain): facies architecture and fault-controlled stratabound dolostones. Cretac. Res. 41, 217-236. https://doi.org/10.1016/j.cretres.2012.12.008.

Martín-Martín, J.D., Travé, A., Gomez-Rivas, E., Salas, R., Sizun, J.-P., Vergés, J., Corbella, M., Stafford, S.L., Alfonso, P., 2015. fault-controlled and stratabound dolostones in the late Aptian-earliest Albian Benassal Formation (Maestrat Basin, E Spain): petrology and geochemistry constrains. Mar. Petrol. Geol. 65, 83-102. https://doi.org/10.1016/j.marpetgeo.2015.03.019.

Martín-Martín, J.D., Gomez-Rivas, E., Gómez-Gras, D., Travé, A., Ameneiro, R., Koehn, D., Bons, P.D., 2018. Activation of stylolites as conduits for overpressured fluid flow in dolomitized platform carbonates. Geol. Soc. Lond. Spec. Publ. 459, 157-176. https://doi.org/10.1144/SP459.3.

Moore, C.H., 2001. Carbonate Reservoirs: Porosity, Evolution and Diagenesis in a Sequence Stratigraphic Framework. Elsevier, 444.

Morad, D., Nader, F.H., Morad, S., Al Darmaki, F., Hellevang, H., 2018. Impact of stylolitization on fluid flow and diagenesis in foreland basins: evidence from an Upper Jurassic Carbonate gas reservoir, Abu Dhabi, United Arab Emirates. J. Sediment. Res. 88 (12), 1345-1361. https://doi.org/10.2110/jsr.2018.70.

Merino, E., 1992. Self-organization in stylolites. Am. Sci. 80, 466.

Miller, J.K., Folk, R.L., 1994. Petrographic, geochemical and structural constraints on the timing and distribution of postlithification dolomite in the Rhaetian Portoro ('Calcare Nero') of the Portovenere area, La Spezia, Italy. In: Purser, B., Tucker, M. Zenger, D. (Eds.), Dolomites: A Volume in Honour of Dolomieu, pp. 187-202. https://doi.org/10.1002/9781444304077.ch12.

Narkiewicz, M., 1979. Telo- and mesogenetic dolomites in subsurface Upper Devonian to Lower Carboniferous sequences of southern Poland. Neues Jahrbuch Geol. Palaontol. Abhand. 158 (2), 180-208.

Nelson, R.A., 1981. Significance of fracture sets associated with stylolite zones. AAPG (Am. Assoc. Pet. Geol.) Bull. 65, 2417-2425. https://doi.org/10.1306/03B599AE16D1-11D7-8645000102C1865D.
Neilson, J.E., Oxtoby, N.H., Simmons, M.D., Simpson, I.R., Fortunatova, N.K., 1998. The relationship between petroleum emplacement and carbonate reservoir quality: examples from Abu Dhabi and the Amu Darya Basin. Mar. Petrol. Geol. 15 (1), 57-72. https://doi.org/10.1016/S0264-8172(97)00033-0.

Neilson, J.E., Oxtoby, N.H., 2008. The relationship between petroleum, exotic cements and reservoir quality in carbonates - a review. Mar. Petrol. Geol. 25, 778-790. https://doi.org/10.1016/j.marpetgeo.2008.02.004.

Olierook, H.K.H., Timms, N.E., Hamilton, P.J., 2014. Mechanisms for permeability modification in the damage zone of a normal fault, northern Perth Basin, Western Australia. Mar. Petrol. Geol. 50, 130-147. https://doi.org/10.1016/j. marpetgeo.2013.10.012.

Peacock, D.C.P., Korneva, I., Nixon, C.W., Rotevatn, A., 2017. Changes of scaling relationships in an evolving population: the example of "sedimentary" stylolites J. Struct. Geol. 118-133. https://doi.org/10.1016/j.jsg.2017.01.012.

Paganoni, M., Al Harthi, A., Morad, D., Morad, S., Ceriani, A., Mansurbeg, H., Al Suwaidi, A., Al-Aasm, I.S., Ehrenberg, S.N., Sirat, M., 2016. Impact of stylolitisation on diagenesis of a Lower Cretaceous carbonate reservoir from a giant oilfield, Abu Dhabi, United Arab Emirates. Sediment. Geol. 335, 70-92. https://doi.org/10.1016/ j.sedgeo.2016.02.004.

Rustichelli, A., Tondi, E., Korneva, I., Baud, P., Vinciguerra, S., Agosta, F., Reuschlé, T., Janiseck, J.M., 2015. Bedding-parallel stylolites in shallow-water limestone successions of the Apulian Carbonate Platform (central-southern Italy). Ital. J. Geosci. 134 (3), 513-534. https://doi.org/10.3301/IJG.2014.35.

Salas, J., Guimerà, J., Mas, R., Martín-Closas, A., Meléndez, A., Alonso, A., 2001. Evolution of the Mesozoic central Iberian rift system and its Cainozoic inversion (Iberian chain). In: Ziegler, P.A., Cavazza, W., Robertson, A.H.F., Crasquin-Soleau, S. (Eds.), Peri-Tethyan Memoir 6: Peri-Tethyan Rift/Wrench Basins and Passive Margins. Mém. Mus. Natn. Hist. . Nat. 186, Paris, pp. 145-185.

Schoenherr, J., Reuning, L., Hallenberger, M., Lüders, V., Lemmens, L., Biehl, B.C., Lewin, A., Leupold, M., Wimmers, K., Strohmenger, C.J., 2018. Dedolomitization: review and case study of uncommon mesogenetic formation conditions. Earth Sci. Rev. 185, 780-805. https://doi.org/10.1016/j.earscirev.2018.07.005.

Stacey, J., Corlett, H., Holland, G., Koeshidayatullah, A., Cao, C., Swart, P., Crowley, S., Hollis, C., 2021. Regional fault-controlled shallow dolomitization of the Middle Cambrian Cathedral Formation by hydrothermal fluids fluxed through a basal clastic aquifer. GSA Bull. https://doi.org/10.1130/B35927.1 (in press).

Staude, S., Bons, P.D., Markl, G., 2009. Hydrothermal vein formation by extension-driven dewatering of the middle crust: an example from SW Germany. Earth Planet Sci. Lett. 286, 387-395. https://doi.org/10.1016/j.epsl.2009.07.012.

Toussaint, R., Aharonov, E., Koehn, D., Gratier, J.P., Ebner, M., Baud, P., Rolland, A., Renard, F., 2018. Stylolites: a review. J. Struct. Geol. https://doi.org/10.1016/j. jsg.2018.05.003.

Tucker, M.J., 2015. Geology, Mineralization and Geochronology of the Conrad Zone Carlin-type Gold Prospect, East-Central Yukon Territory, Canada. MSc thesis, University of British Columbia. https://doi.org/10.14288/1.0166106.

Vandeginste, V., John, C.M., 2013. Diagenetic implications of stylolitization in pelagic carbonates, Canterbury Basin, offshore New Zealand. J. Sediment. Res. 83 (3), 226-240. https://doi.org/10.2110/jsr.2013.18.

Van Geet, M., Swennen, R., Wevers, M., 2001. Towards 3-D petrography: application of microfocus computer tomography in geological science. Comput. Geosci. 27 (9), 1091-1099. https://doi.org/10.1016/S0098-3004(00)00154-0. DOI: 10.1016/ S0098-3004(00)00154-0.

Whitaker, N., Smart, P., Jones, G., 2004. Dolomitization: from conceptual to numerical models. In: The Geometry and Petrogenesis of Dolomites Hydrocarbon Reservoirs, vol. 235. Geological Society, London, Special Publications, pp. 99-139. https://doi. org/10.1144/GSL.SP.2004.235.01.05.

Yao, S., Gomez-Rivas, E., Martín-Martín, J.D., Gómez-Gras, D., Travé, A., Griera, A., Howell, J., 2020. Fault-controlled dolostone geometries in a transgressive-regressive sequence stratigraphic framework. Sedimentology 67, 3290-3316. https://doi.org/ 10.1111/sed.12739. 